\title{
Prevalence and co-infection study of Chlamydia trachomatis, Neisseria gonorrhoeae, and Trichomonas vaginalis among symptomatic women using PCR assay
}

\author{
SC Sonkar ${ }^{1}$, K Wasnik ${ }^{1}$, PK Mishra ${ }^{1}$, P Mittal ${ }^{2}$, A Kumar $^{2}$, J Suri ${ }^{2}$, D Saluja ${ }^{1 *}$ \\ From 2nd International Science Symposium on HIV and Infectious Diseases (HIV SCIENCE 2014) \\ Chennai, India. 30 January - 1 February 2014
}

\section{Background}

Sexually transmitted infections (STIs) are one of the major causes of acute illness, infertility, long term disability and death for millions of men, women and infants globally. Trichomonas vaginalis, Neisseria gonorrhea and Chlamydia trachomatis are well established agents of STIs leading to vaginal discharge in women. However, the prevalence and co infection patterns among symptomatic women is lacking in India. The present study aims to determine the prevalence and co infection of Chlamydia trachomatis, Neisseria gonorrhoeae and Trichomonas vaginalis, in women with vaginal discharge attending OPD, Vardhman Mahavir Medical College and Safdarjung Hospital, New Delhi.

\section{Methods}

Dry swab samples were obtained and DNA was extracted used as template for PCR amplification using primers targeting $p f o B$, gyr $A$ and orf1 gene for diagnosis of $T$. vaginalis, $C$. trachomatis and $N$. gonorrhoeae respectively to estimate prevalence of co-infection.

\section{Results}

A total of 335 women were studied (mean age 23.2 years), out of which 22 women $(6.56 \%)$ women were infected with had at least one pathogen. One woman $(4.54 \%)$ was co-infected with all three pathogens. Amongst 335 women, 18 women $(5.37 \%)$ tested positive for $T$. vaginalis, 02 women $(0.59 \%)$ tested positive for $C$. trachomatis and

\footnotetext{
* Correspondence: dsalujach59@gmail.com

${ }^{1}$ Dr. B. R. Ambedkar Center for Biomedical Research, University of Delhi, Delhi-110007, India

Full list of author information is available at the end of the article
}

1 woman $(0.29 \%)$ tested for $N$. gonorrhea by all the PCR assays, whereas 313 women (93.43\%) tested negative for the all three pathogens.

\section{Conclusion}

The results demonstrated that it is necessary to test for all three pathogens namely $T$. vaginalis, $N$. gonorrhea and $C$. trachomatis in women with vaginal discharge.

\section{Authors' details}

'Dr. B. R. Ambedkar Center for Biomedical Research, University of Delhi, Delhi-1 10007, India. ${ }^{2}$ Department of Obstetrics \& Gynecology Vardhman Mahavir Medical College and Safdarjung Hospital, New Delhi-110029, India.

\section{Published: 27 May 2014}

doi:10.1186/1471-2334-14-S3-P5

Cite this article as: Sonkar et al:: Prevalence and co-infection study of Chlamydia trachomatis, Neisseria gonorrhoeae, and Trichomonas vaginalis among symptomatic women using PCR assay. BMC Infectious Diseases 2014 14(Suppl 3):P5.

Submit your next manuscript to BioMed Central and take full advantage of:

- Convenient online submission

- Thorough peer review

- No space constraints or color figure charges

- Immediate publication on acceptance

- Inclusion in PubMed, CAS, Scopus and Google Scholar

- Research which is freely available for redistribution 